\title{
Aeroexpress public transport system introduction in Almaty and its impact on greenhouse gases emissions decrease in Almaty city transport sector
}

\author{
Vera Rakova $^{1, \mathrm{a}}$, Xeniya Rakova ${ }^{2, \mathrm{~b}}$, Tatyana Musorina ${ }^{3, \mathrm{c}}$ \\ ${ }^{1}$ Nurmakova street 1/1, 050026, Almaty, Kazakhstan \\ ${ }^{2,3}$ Saint-Petersburg State Polytechnical University, Russian Federation \\ averarakova@gmail.com,.b4uik@mail.ru, flamingo-93@mail.ru
}

\begin{abstract}
In Almaty, there are currently more than 500,000 vehicles registered and there is an average of another $\mathbf{2 0 0 , 0 0 0}$ vehicles that enter the city from outlying Almaty Oblasts during working hours. The road network of Almaty has not grown since 1990 when the municipality estimated the number of cars in Almaty to be 100,000.

Almaty public transport system degrade and became ineffective with significant loss of safety and comfort level by the reason of privatization and occurring of "shadow" taxi at the service market. [1]

Almaty airport is not connected with railway stations Almaty 1, Almaty 2 and city center by a straight and comfortable public transport route. Thus, the prevailing number of airport visitors prefer travelling on personal transport or taxi. Which is, in turn, brings a negative environmental loads. In current circumstances, the Moscow Aeroexpress transport analogue may become a good solution for Almaty.
\end{abstract}

Keywords: public transport, greenhouse gases, pollutants, emissions decrease, sustainable transport

\section{INTRODUCTION}

The primary impacts of this economic growth during 1990s-2000s in Almaty as well as other cities of the former Soviet Union are:

- growth of urban sprawl of these cities, and the rapid increase in the use of private motor vehicles for urban transport;

- large increases in traffic congestion in these cities particularly during peak hours; and

- $\quad$ irregular development of public transport and an associated deterioration in the quality of service delivery.

The viable alternative to private cars should be public transport. Unfortunately, Almaty's public transport has evolved into a system that does not provide for comfort, convenience and efficient services to commuting passengers. Currently, almost all public transport has been privatized; only electric transport (i.e. trolleybuses and trams) is still owned and managed by the municipality under Almatyelectrotrans, a public utility company. Their service, however, is unable to compete with individual cars and private bus operators.

Almaty's public transit has evolved into a system characterized by:

poorly maintained aged vehicles; overcrowding especially at peak hours that allows bus operators to maximize profits;

lack of services in off-peak hours;

poor mobility on roads due to traffic congestion and lack of priority for buses; and

- a lack of cleanliness on board. These complaints, however, remain unaddressed by private bus operators, while the municipality lacks control and enforcement mechanisms to ensure compliance of operators with technical and safety regulations and schedules. [1]

Almaty underground may become a good solution as a safe, regular and comfortable transport. But such barriers as small line distance $11,52 \mathrm{~km}$ including Sairan and Moscow stations low work load and absence of on ground transport infrastructure connected to underground make it less effective than in other cities. This fact is also aggravated by worsening of economical conditions which followed by the republic of Kazakhstan president proposal to cut funding of underground second turn construction funding. [2]

Thus, soon organization of sustainable passenger transport channel connecting railway station Almaty-1 with the city center turns questionable. Which reflects 
negatively on Almaty environmental conditions as personal transport has significant advantages in this circumstances.

Current paper goal is the evaluation of greenhouse gases (GHG) emission decrease by the introduction of Moscow Aeroexpress public transport system introduction for connection of Almaty city airport on the travel line: Almaty city airport - railway station Almaty 1, railway station Almaty 2, Rosy Bakieyv str./ Tole Bi str. cross (AZTM plant in previous) and definition of other possible positive impacts from such transport system implementation.

Almaty airport is connected with Almaty center by the automobile road (travel time by a taxi or private transport is about 15-30 minutes, depending on the traffic). The airport passenger turnover was 4589000 of people in 2014 year [3], which is about 12572 of people per day.

By the reason of high traffic loads during the rush hours travel time might rise for several times. Which, in turn, brings a negative environmental load of ineffective automobile engines functioning "stop slow wheeling" regime.

By the experts evaluation, the $\mathrm{CO} 2$ emissions from Almaty automobile transport in 2015 year will become 16,8 million of tones, in $2020-24.0$ million of tones.[1]

\section{EMISSIONS CALCULATION METHODOLOGY}

Transport GHG emissions calculation at the route
Almaty airport - Almaty-1 railway station - Almaty-2 railway station - Rozy Bakiyev street and Tole bi street crossing were made according to the United Nations Framework Convention on Climate Change (UNFCCC) \Intergovernmental Panel on Climate Change (IPCC) "Good Practice Guidance and Uncertainty Management in National Greenhouse Gas Inventories" [4] and National "Road transport GHG atmosphere emissions and emissions reduction calculation methodology" document project [5], containing national emission factors.

The next equations were used:

Fuel consumptionij $=\mathrm{nij} * \mathrm{kij} *$ eij,

where: $\mathrm{i}=$ transport kind,

$\mathrm{j}=$ fuel kind,

$\mathrm{n}=$ transport quantity,

$\mathrm{k}=$ kilometers quantity per year [4]

$$
\text { Emissions }=44 / 12 \sum(\text { Fuel } * \mathrm{EFa})
$$

where:

«Emissions» - emissions in $\mathrm{kg}$;

Fuel - quantity of fuel burnt in $\mathrm{TJ}$;

$\mathrm{EFa}-\mathrm{CO}_{2}$ emission factor, equal to carbon content in one fuel kind $(\mathrm{kg} / \mathrm{TJ})$;

$\mathrm{a}-$ fuel kind (gasoline, diesel fuel, etc.). [5]

\section{INITIAL DATA}

Analyzing transport routes using online service Google maps and other reference [8, 10,12], the initial calculation data are represented in tables 1-3.

Table 1 - Information on contemplated route parts length. $[8,10]$

\begin{tabular}{|c|c|c|c|}
\hline Route part & $\begin{array}{l}\text { Average one way } \\
\text { length by car }\end{array}$ & $\begin{array}{l}\text { Public transport } \\
\text { routes }\end{array}$ & $\begin{array}{l}\text { Average one way } \\
\text { length by bus }\end{array}$ \\
\hline $\begin{array}{l}\text { Almaty airport (Akhmetov str./Maylin str. crossing) - Almaty-1 } \\
\text { railway station }\end{array}$ & $8,7 \mathrm{~km}$ & Bus №106 & $8 \mathrm{~km}$ \\
\hline Almaty-1 railway station - Almaty-2 railway station & $9,5 \mathrm{~km}$ & Bus №2, №73 & $9,25 \mathrm{~km}$ \\
\hline $\begin{array}{l}\text { Almaty-2 railway station - Rozy Bakiyev street and Tole bi street } \\
\text { crossing }\end{array}$ & $6,5 \mathrm{~km}$ & $\begin{array}{ll}\text { Bus } & \text { №37, } \\
\text { №59,№100 }\end{array}$ & $6,43 \mathrm{~km}$ \\
\hline $\begin{array}{l}\text { Almaty airport (Akhmetov str./Maylin str. crossing) - Almaty-2 } \\
\text { railway station }\end{array}$ & $12,7 \mathrm{~km}$ & $\begin{array}{l}\text { Bus №86, №92, } \\
\text { №79 }\end{array}$ & $12,2 \mathrm{~km}$ \\
\hline $\begin{array}{l}\text { Almaty airport (Akhmetov str./Maylin str. crossing) - Rozy } \\
\text { Bakiyev street and Tole bi street crossing }\end{array}$ & $18,3 \mathrm{~km}$ & Bus №106 & $25 \mathrm{~km}$ \\
\hline \multicolumn{4}{|c|}{$\begin{array}{l}\text { Note: *from the airport territory during the night time there is one bus route № } 3 \text { to the city center which was not taken into } \\
\text { account as the route as uncompetitive with the daytime routes. } \\
\text { **From the closest to airport bus station (Akhmetov str./Maylin str. crossing) moving one more route №10 which was also not } \\
\text { taken into account as uncompetitive for the route length. }\end{array}$} \\
\hline
\end{tabular}

Table 2 - Airport - city center routes timetable. [9]

\begin{tabular}{|l|l|l|}
\hline Route number & Working hours & Time interval \\
\hline 100 & $6.00-23.40$ & 6 мин. \\
\hline 106 & $5.26-23.26$ & 8 мин. \\
\hline 2 & $6.10-24.00$ & 7 мин. \\
\hline 27 & $6.30-23.00$ & 5 мин. \\
\hline 37 & $6.00-23.45$ & 5 мин. \\
\hline 59 & $6.00-23.53$ & 6 мин. \\
\hline 73 & $6.10-24.00$ & 5 мин. \\
\hline 79 & $6.00-00.00$ & 6 мин. \\
\hline 86 & $6.00-23.30$ & 7 мин. \\
\hline 92 & $5.30-00.10$ & 6 мин. \\
\hline 96 & $5.30-00.10$ & $5-6$ мин. \\
\hline
\end{tabular}


Environment. Technology. Resources, Rezekne, Latvia Proceedings of the $10^{\text {th }}$ International Scientific and Practical Conference. Volume II, 251-255

Current paper according major requirements of "Good Practice Guidance and Uncertainty Management in National Greenhouse Gas Inventories"[4] contains disaggregation of transport flow by transport type (gasoline, diesel, natural gas, liquid gas).Table 3 represents required data disaggregation with information on fuel consumption per $1 \mathrm{~km}$.

Table 3 - Transport flow by kind and fuel disagregation.

\begin{tabular}{|c|c|c|c|c|c|c|}
\hline & Transport kind & Body type & Model & Fuel type & $\begin{array}{l}\text { Fuel } \\
\text { consumption, } \\
\text { 1/ } 100 \mathrm{~km}\end{array}$ & $\begin{array}{c}\text { Fuel } \\
\text { consumption, } \\
1 / 1 \mathrm{~km}\end{array}$ \\
\hline \multirow{10}{*}{ 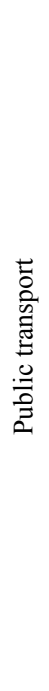 } & Route№79 & Bus & \multirow{5}{*}{$\begin{array}{l}\text { Yutong } \\
\text { ZK6120HGM }\end{array}$} & \multirow{5}{*}{ Compressed gas } & 30 & 0,3 \\
\hline & Route№2 & Bus & & & 30 & 0,3 \\
\hline & Route№92 & Bus & & & 30 & 0,3 \\
\hline & Route№73 & Bus & & & 30 & 0,3 \\
\hline & Route№37 & Bus & & & 30 & 0,3 \\
\hline & Route№86 & Bus & Hyundai & \multirow{5}{*}{ Diesel } & 22 & 0,22 \\
\hline & Route№100 & Bus & HYUNDAI & & 22 & 0,22 \\
\hline & Route№106 & Bus & MAN & & 35 & 0,35 \\
\hline & Route№27 & Bus & DAEWOO & & 22 & 0,22 \\
\hline & Route№ 59 & Bus & DAEWOO & & 22 & 0,22 \\
\hline \multirow{4}{*}{ 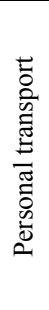 } & Eco taxi & Light vehicle & $\begin{array}{l}\text { SsangYoung } \\
\text { Kyron }\end{array}$ & Liquid gas & 16,85 & 0,17 \\
\hline & Unoffical taxi & Light vehicle & - & Gasoline & 9,3 & 0,09 \\
\hline & Private vehicle & Light vehicle & - & Gasoline & 16,7 & 0,17 \\
\hline & Private vehicle & $\begin{array}{l}\text { General purpose } \\
\text { vehicle, off-road } \\
\text { vehicle }\end{array}$ & - & Diesel & 13 & 0,13 \\
\hline
\end{tabular}

\section{ESTIMATION}

According to observations, from the airport territory and the near bus station by routes №№79, $86,92,106$ by every travel arrive/ depart about 3 passengers. Thus, as the airport annual passenger turnover, passenger turnover per day 12572 we obtained the quantity of airport visitors using public transport. (Table 4).

Table 4 - Airport visitors quantity by routes.

\begin{tabular}{|l|l|l|l|}
\hline Route number & Working hours quantity per day. & Route tour quantity per day. & $\begin{array}{l}\text { Airport visitors passengers } \\
\text { quantity per day }\end{array}$ \\
\hline 79 & 18 & 180 & 540 \\
\hline 86 & 17 & 150 & 450 \\
\hline 92 & 19 & 190 & 570 \\
\hline 106 & 18 & 135 & 405 \\
\hline Total & 555 & 1965 \\
\hline
\end{tabular}

Considering obtained figure 1965 public transport passengers one may resume that 10607 $(84,4 \%)$ airport visitors use personal transport (private vehicles, taxi, unofficial taxi).
Using coefficient 0,5 to determine vehicle quantity streaming to the city center from the airport, thus obtaining 5303 passengers per day.

According to visual analysis of airport parking content about $24 \%$ of transport are general purpose 
vehicles. As the significant share in off road transport has diesel engines, we consider that 1273 diesel cars arrive/ depart to airport parking per day. About $10 \%$ of vehicles are equipped with gas engines (municipal taxi service "Eco taxi") which is equal to 530 cars arriving and departing from the airport territory per day.

Using the above appointed figures one can calculate GHG emissions (Table5).

Table 5. - Transport flow $\mathrm{CO}_{2}$ - equivalent GHG emissions results.

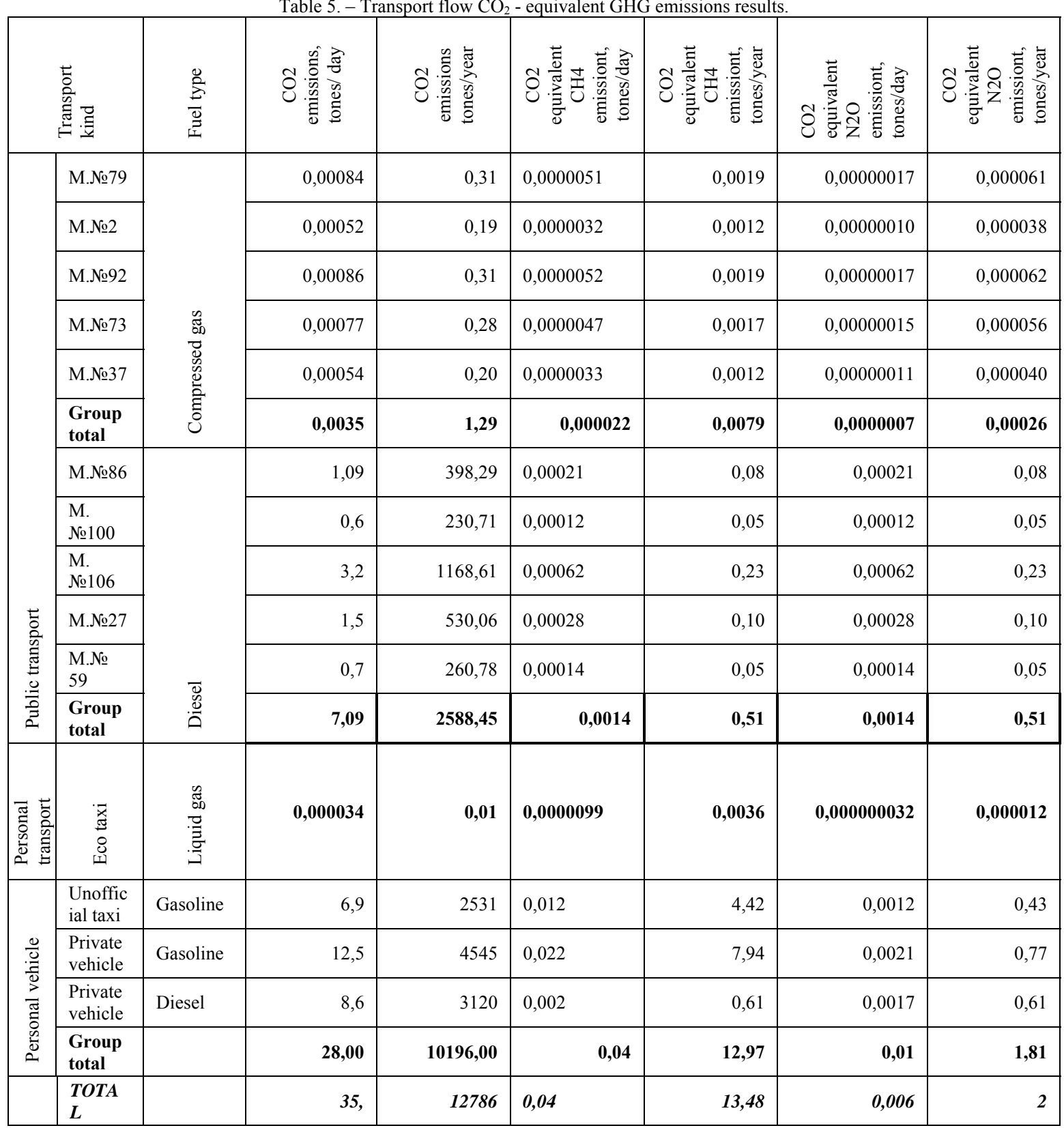

Discussion. Analysing the GHG emissions figures it is clear that the most input occurs from private vehicles functioning on gasoline and diesel fuel. The considered public transport input occurs only from Diesel engine buses and equal to $20 \%$ vs.79, $8 \%$ from private vehicles (Diagram 1). 
Vera Rakova, et al./ Environment. Technology. Resources, (2015), Volume II, 251-255

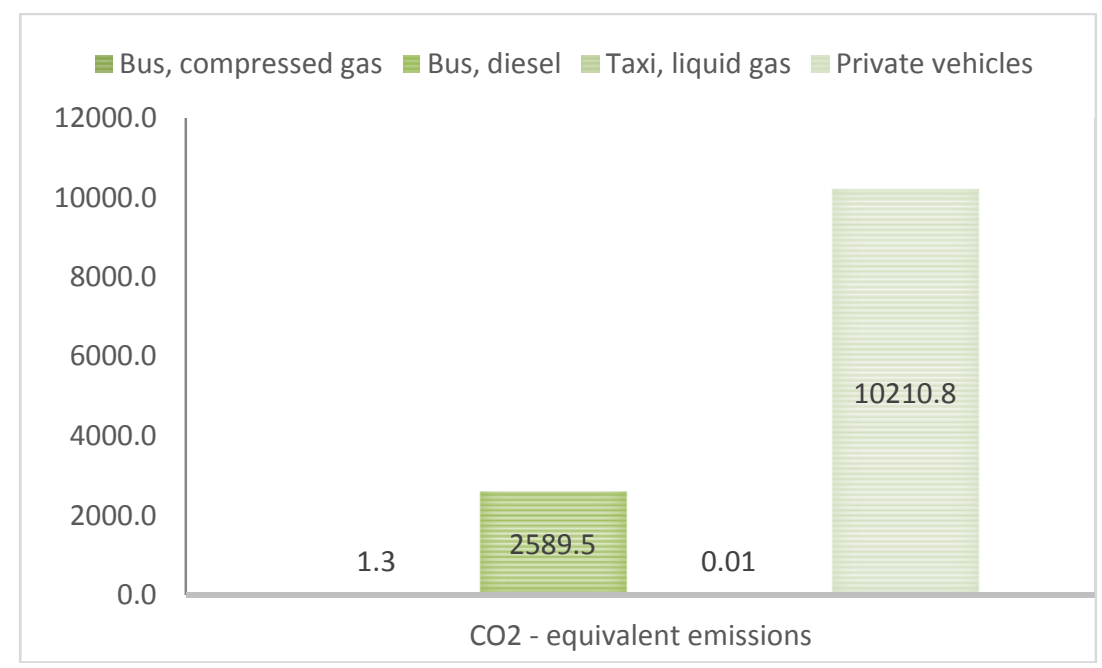

Diagram1 - GHG emission from various transport kinds within the explored route transport flow.

\section{$\mathrm{V}$ CONCLUSIONS}

1. As one can see the analogue of Moascow city Airexpress transport system functionin at the line Almaty city airport - railway station Almaty 1, railway station Almaty 2, Rosy Bakieyv str./ Tole Bi str. cross providing regular passenger conveyance along with some restrictions in separate groups of vehicles entering to the airport territory, excluding public transport, official taxi and flight passengers personal vehicles can decrease GHG emissions up to $5700-2500$ tones annually.

2. Such measures will promote public transport infrastructure turning it to more sustainable transport system and improving passenger conveyance safety and comfort.

3. This introduction will positively reflect on Almaty city environmental conditions and reputation as of the modern mainstreaming city and meeting its obligations in terms of international agreements and conventions.

\section{REFERENCES}

[1]. Republic of Kazakhstan United Nations Development Programme "City of Almaty Sustainable Transport" PROJECT DOCUMENT http://www.undp.kz/projects/files/237-15778.pdf
[2]. International News Agency Kazinform "N. Nazarbayev proposed to cut funding of Universidad and underground construction", 11 February of 2015, 13:27 http://inform.kz/rus/article/2745265

[3]. News Agency Interfax "Almaty Airport increased passenger flow on $6 \%$ in 2014 year" 20 January of 2015 year

https://www.interfax.kz/?lang=rus\&int_id=22\&news_id= 13958

[4]. United Nations Framework Convention on Climate Change (UNFCCC) $\backslash$ Intergovernmental Panel on Climate Change (IPCC) "Good Practice Guidance and Uncertainty Management in National Greenhouse Gas Inventories" http://www.ipcc-

nggip.iges.or.jp/public/gp/english/gpgaum en.html

[5]. Republic of Kazakhstan Ministry of Energy document project "Road transport GHG atmosphere emissions and emissions reduction calculation methodology"

[6]. "Rate of petroleum, oil and lubricants use for automobile transport ownership" document №1210 stated by the Republic of Kazakhstan government on August, 11 of 2009.

[7]. Finnish Environment Institute Air Pollutant Emission Factor Library http://www.apef-library.fi/

[8]. Google maps service https://www.google.com/maps/@43.3098964,76.9480809 , $13 \mathrm{z}$

[9]. Public transport administration press service and "Almaty center of information technologies", LLP joint project.

[10].Passengers internet service "Za proezd.kz": http://zaproezd.kz/

[11]. I. K. Kikoin "Tables of physical quantities. Data book." Moscow: Atmoizdat, 1976. - 1008 p.

[12]. Almaty underground official web page: http://metroalmaty.kz/?q=ru 